\title{
Facies Interpretation, Depositional Environment and Sequence Stratigraphy of the Gachal Formation in the Madbeiki Section, Kalmard Block, East Central Iran
}

\author{
Soheil Erfani ${ }^{*}$, Mohammad Hossein Adabi², Mahmood Reza Majidifard ${ }^{3}$, \\ Nader Kohansal Ghadimvand ${ }^{4}$ \\ ${ }^{1}$ Department of Geology, North-Tehran Branch, Islamic Azad University, Tehran, Iran \\ ${ }^{2}$ Department of Geology, Faculty of Earth Sciences, Shahid Beheshti University, Tehran, Iran \\ ${ }^{3}$ Research Institute for Earth Sciences, Geological Survery of Iran, Tehran, Iran \\ ${ }^{4}$ Department of Geology, Islamic Azad University North-Tehran Branch, Tehran, Iran \\ Email: *S_erfani87@yahoo.com
}

Received 3 May 2016; accepted 24 June 2016; published 27 June 2016

Copyright (C) 2016 by authors and Scientific Research Publishing Inc.

This work is licensed under the Creative Commons Attribution International License (CC BY). http://creativecommons.org/licenses/by/4.0/

(c) (i) Open Access

\begin{abstract}
Deposits of Lower Carboniferous rocks in Kalmard block are recognized by Gachal informal formation, showing various characteristics in different outcrops. Lower Carboniferous deposits (Gachal formation) are composed chiefly of carbonate, evaporite and siliciclastic rocks. This formation is composed of $198 \mathrm{~m}$ sandstone, limestone and dolomite as well as a small amount of shale, marl and gypsum in the Madbeiki section. This formation unconformably underlies Precambrian metamorphic deposits (Kalmard formation) while lateritic soils of lower Permian (Chili formation) are depicted overlying an erosional unconformity above this formation. According to lithologic and microscopic investigations, the deposits of Gachal formation can be divided into 1 siliciclastic petrofacies, 1 evaporite microfacies and 16 carbonate microfacies. Field observations, along with microscopic examinations, have resulted in identifying tidal flat, lagoon, shoal and open marine environments in the rocks of the studied formation. Vertical changes of microfacies and depth variation curve indicate the high thickness of the microfacies of tidal flat, lagoon and shoal environments and low thickness of the microfacies of open marine environment. The carbonateevaporite-siliciclastic sequence of Gachal formation is made up of three third-order depositional sequence, separated each other by type 1 sequence boundary (SB1). Siliciclastic and evaporite deposits include LST system tract, and carbonate microfacies involve TST and HST system tracts, separated from each other by MFS. Gachal formation rocks in Madbeiki section are deposited in a low-angle homoclinal ramp, mostly in the inner ramp, located in the southern Paleotethys Ocean.
\end{abstract}

\footnotetext{
${ }^{*}$ Corresponding author.
}

How to cite this paper: Erfani, S., Adabi, M.H., Majidifard, M.R. and Ghadimvand, N.K. (2016) Facies Interpretation, Depositional Environment and Sequence Stratigraphy of the Gachal Formation in the Madbeiki Section, Kalmard Block, East Central Iran. Open Journal of Geology, 6, 440-458. http://dx.doi.org/10.4236/ojg.2016.66037 
The depositional sequence identified in Gachal formation points to the age of Lower Carboniferous, conforming to upper Kaskaskia super sequence. The upper erosional boundary between Gachal and Chili formations conform to the global-scale sea level fall.

\title{
Keywords
}

\author{
Lower Carboniferous, Kalmard Block, Gachal Formation, Depositional Environment, Sequence \\ Stratigraphy
}

\section{Introduction}

Central Iran, shaped like a triangle and as one of the major, largest and most complex geological units in Iran, is located in the center of Iran. Structural model of this area consists of separate blocks, separated by deep faults, and thus enjoy distinct characteristics. Kalmard Block, enjoying a northeastern trend, is situated between Kalmard faults in the east and those of Naein in the west [1].

\section{Madbeiki Section Position}

This section is located in the western Tabas (at 1:250,000 scale) [2] and northeast of Robat-e-khan village in Kalmard zone (at 1:100000 scale) [3] (eastern central Iran). It is formed by geographical coordinates of $33^{\circ} 29^{\prime} 6^{\prime \prime} \mathrm{N}$ and $56^{\circ} 15^{\prime} 21$ "E, and is located about 88 kilometers from Tabas-Ardekan old main road, accessible by a one-kilometer-dirt road (Figures 1-3).

\section{Methodology}

To determine the facies characteristics and depositional environment conditions as well as the sequences in this section, the geological maps of Tabas (at 1:250,000 scale) [2] and Robat-e-khan (at 1:100,000 scale) [3] are employed and then the required data are collected though examining literature including textbooks, papers, reports, etc. Regarding field observations, the lithological characteristics of the sequence including gradation, various depositional structures, various fossils and parasequences stacking pattern are recorded, and major stratigraphic surfaces such as maximum flood surface (MFS), sequence boundaries (SB) and transgressive surface (TS) are recognized. According to laboratory investigations, moreover, carbonate microscopic thin sections are used to reveal the characteristics of microscopic facies (namely, grain size and other textual features), diagenetic characteristics and microfossils. The petrofacies of siliciclastic rocks are identified by studying thin sections. Having collected data from thin sections, the depositional environment of this formation is interpreted and explained. Field and microscopic evidence is also used to discuss the sequence stratigraphy of the studied sequence. Next, parasequences stacking pattern, unconformity surfaces, system tracts and the status of the studied sequence stratigraphy among the global sequences are also determined. Adopting Dickson's 1965 method [4], Alizarin-red is used to stain the thin sections to identify the type of carbonate minerals (distinguishing calcite from dolomite). Folk classification scheme [5] is used to classify siliciclastic petrofacies, and Dunham (1962) classification system [6], refined by Emry \& Klovan in 1971 is employed to describe the composition of the carbonate microfacies [7]. Additionally, a comparison is made between vertical changes of microfacies and recent depositional environment using information gathered from Wilson, 1975; Carozzi, 1989; Tucker \& Wright, 1990; Flügel, 2010 [8]-[11]. Having studied various methods in sequence stratigraphy studies, the depositional sequence model devised by Posamentier (1988) is used [12]. Regarding this model, "sequence stratigraphy" involves the study of rock relationships within the chronostratigraphic framework of a sequence, which in turn is a cyclic succession of rocks composed of genetically related units of strata [12]. Finally, all information and data are combined, interpreted and explained.

\section{Stratigraphy}

Lower Carboniferous rocks deposit (Tournaisian-Vizean-Serpukhovian stages), composed of limestone, dolomitic limestone, dolomite and gypsum as well as a small amount of sandstone in its lower parts [1], are recognized 


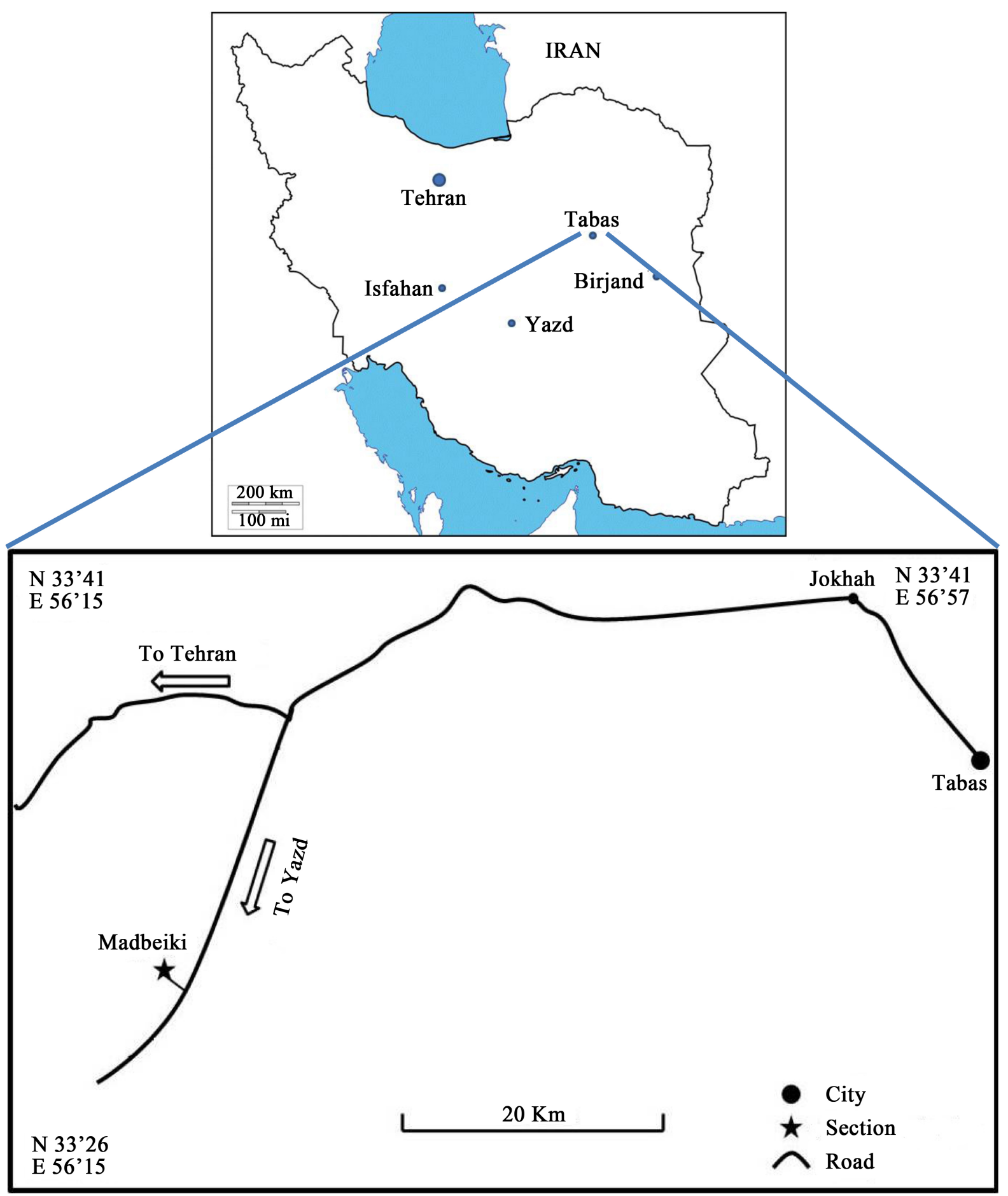

Figure 1. Geographical position and access way to Gachal formation in Madbeiki section.

in Kalmard block by Gachal informal formation. One of the most comprehensive outcrops of Gachal formation is located in Madbeiki section, in which deposits of Gachal formation rocks have Strike S 15 W, Dip 35 SE and $198 \mathrm{~m}$ thickness. The lithology of Gachal formation in Madbeiki section is composed chiefly of sandstone, limestone, dolomite and a small amount of shale, marl and gypsum. Based on morphologic and lithologic characteristics, this section can be divided into nine units including: white gypsy marl with $0.5 \mathrm{~m}$ in thickness (unit 1), unconformably overlying Precambrian metamorphic deposits (Kalmard formation), a sequence of thick- 


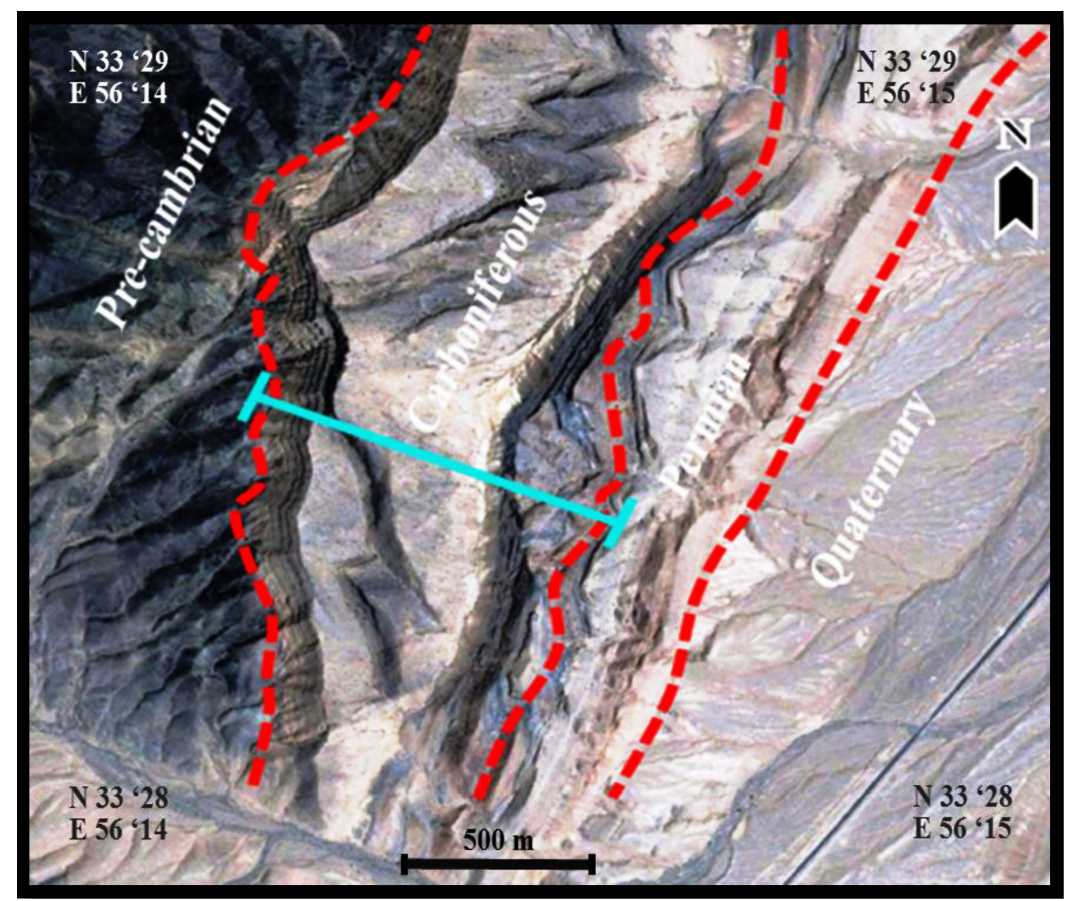

Figure 2. Satellite image of Gachal formation in Madbeiki section, separation of sediments age based on Tabas map (at 1:250,000 scale) (Aghanabati, 1977).

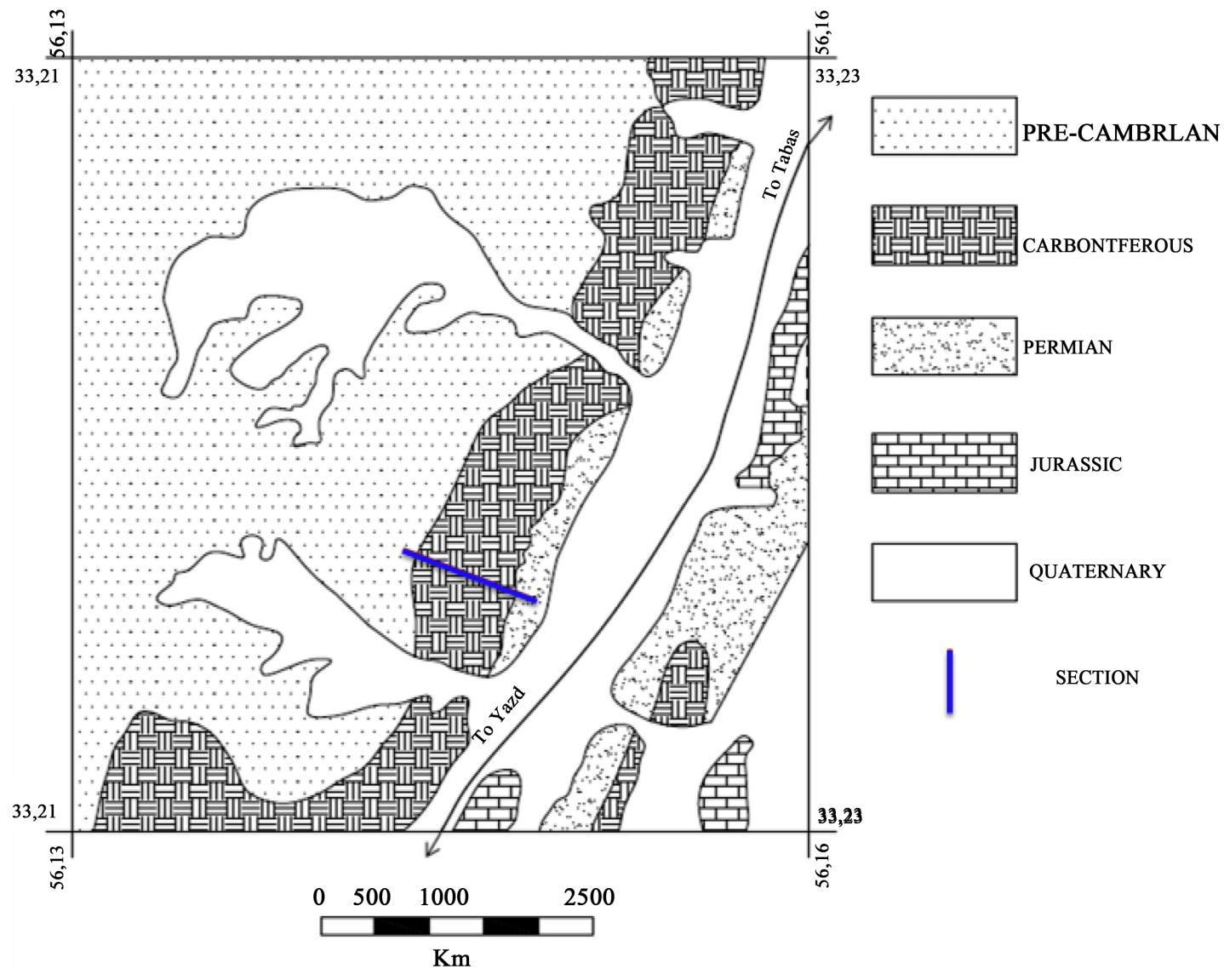

Figure 3. Geological map of Gachal formation in Madbeiki section (Aghanabati, 1977). 
to-medium bedded, red dolomitic sandstone and thick-to-medium bedded, yellow dolomite with $10.5 \mathrm{~m}$ in thickness (unit 2), thick-to-medium bedded, red sandstone with $4 \mathrm{~m}$ in thickness (unit 3), a sequence of thick-tothin bedded dolomitic sandstone and gray dolomitic limestone with horizontally stratified and $65 \mathrm{~m}$ in thickness (unit 4), horizontally stratified, thick-to-thin bedded, dark gray dolomitic limestone with $49 \mathrm{~m}$ in thickness (unit 5), a sequence of horizontally stratified, medium-to-thin bedded, yellow to green dolomite, shale and gypsy marl with thickness of $30 \mathrm{~m}$ (unit 6), horizontally stratified, thick-to-thin bedded, gray limestone along with thinning-upward cycles with $14 \mathrm{~m}$ in thickness (unit 7), highly bioturbated, horizontally stratified, thick-to-medium, red sandstone with thickness of $7 \mathrm{~m}$ (unit 8) and horizontally stratified, thick-to-thin bedded, gray limestone along with thinning-upward cycles with $18 \mathrm{~m}$ in thickness (unit 9). The unit unconformably underlies red, lateritic sandstone of Chili formation (lower Permian).

\section{Investigating the Facies and Depositional Environment of Gachal Formation in Madbeiki Section}

Lithologic and microscopic studies reveal that this sequence consists of one siliciclastic petrofacies, one evaporite microfacies and sixteen carbonate microfacies. These evaporite-carbonate microfacies and siliciclastic petrofacies of Gachal formation are deposited on four facies belts including Tidal flat environment (A), Lagoon environment (B), Shoal environment (C) and Open marine environment (D). These facies belts, facing sea from the coast, include:

\subsection{Facies Belt A: Tidal Flat Environment}

This facies belt includes one petrofacies and five microfacies. A1 is an evaporite microfacies, A2-A5 are carbonate microfacies and A6 is a siliciclastic petrofacies. These petrofacies and microfacies are deposited in supertidal and intertidal subenvironments, described as follow:

$\mathrm{A}_{1}$ : Gypsiferous Mudstone

This microfacies consists of $30 \%$ gypsum crystals with less than $0.1 \mathrm{~mm}$ in size, scattered in a micritic matrix (Figure 4(a)).

$\mathrm{A}_{2}$ : Evaporites Dolomudstone

This microfacies includes gypsum evaporite dolomudstone (Figure 4(b)).

$\mathrm{A}_{3}$ : Dolomitized Fenestral Stromatolite Boundstone

This microfacies consists of 50\% cyanobacteria algae and Bird's-eye and fenestral fabric. Cyanobacteria algae can be found in laminated and boundstone form. It is noteworthy that dolomitization can also occur in this microfacies (Figure 4(c)).

$\mathrm{A}_{4}$ : Fenestral Mudstone

This microfacies, lacking allochem, is a dolomitized fenestral or bird's-eye mudstone, interbeded in a limemud matrix (Figure 4(d)).

$\mathrm{A}_{5}$ : Fenestral Intraclast Algal Packstone

This microfacies is made up of 65\% cyanobacteria algae, $20 \%$ intraclast and fenestral and bird's-eye fabric, interbeded in a lime mud matrix. The average size of the grains is reported to be $0.2 \mathrm{~mm}$ (Figure 4(e)).

$\mathrm{A}_{6}$ : Quartzarenite

This petrofacies contains more than 95\% $0.5 \mathrm{~mm}$-sized, mature, relatively well-rounded and well-sorted grains and quartzarenite petrofacies (Figure 4(f)).

\section{Interpretation}

Microfacies and petrofacies in tidal flat environment are formed in the semi-arid to arid supertidal and intertidal subenvironments. Microfacies $A_{1}$, a mudstone filled with abundant evaporite minerals and interlayered with gypsum, points to the deposition of this microfacies within supratidal subenvironment [13] [14] and hot and humid climate [15].

Due to the intermediate environment of the facies formation, their deposits are moved out of water regularly and irregularly and show certain characteristics, among which one can point to the gypsum crystals, likely formed in the supratidal or Sabkha subenvironment. Todays, these evaporite minerals can be found in supratidal environment is Texas or southern coastlines of Persian Gulf and Mediterranean Sea [16]-[18]. Presence of these minerals suggests an average temperature of higher than $22^{\circ} \mathrm{C}$ and a seasonal temperature of more than $35^{\circ} \mathrm{C}$ [10]. 

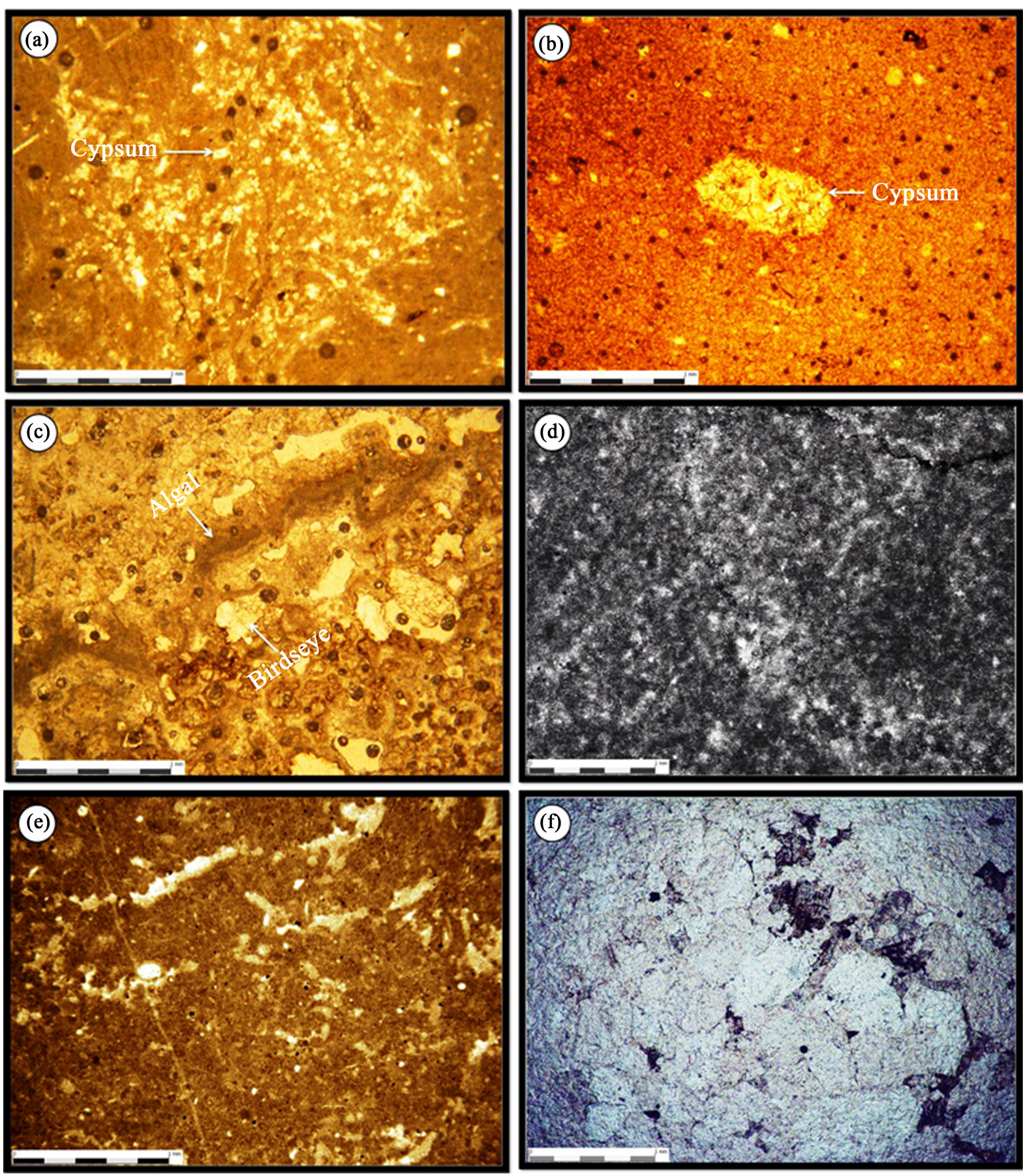

Figure 4. Evaporite and carbonate microfacies and Siliciclastic petrofacies of tidal flat environment in Gachal formation, Madbeiki section (a) gypsiferous mudstone (b) evaporite dolomudstone (c) dolomitized fenestral stromatolite boundstone (d) fenestral mudstone (e) fenestral intraclast algal packstone (f) quartzarenite. $1 \mathrm{~mm}$ scale.

Gypsum crystals are formed in supratidal subenvironment as a result of the high evaporation, resulting in absorbing calcium and creating fine-crystal dolomitic dolomicrite [16] [19]. Microfacies $\mathrm{A}_{2}$, as a fine-crystal dolomite or dolomicrite, is known as type 1 dolomite. The size of crystals in these dolomites is about 5 - 6 microns and is usually formed within supratidal subenvironment due to its fine crystals, maintaining its original texture and lack of fossil. These types of dolomites are called secondary dolomites, formed in the early stages of diagenesis. Sea water and interparticle solutions saturated with $\mathrm{Mg}$ are reported to be the likely causes of dolomitization 
[20]. Mudstone is formed as a primary dolomite (Sabkha) in the supratidal subenvironment (dolomicrite) after formation of evaporite minerals due to the exit of sulfate ions from environment [21].

Fenestral fabric is formed as a result of dehydration and burrowing activities of worms and insects and extended within microfacies $\mathrm{A}_{3}-\mathrm{A}_{5}$ [13] [14]. Microfacies $\mathrm{A}_{3}$ consists of stromatolitic bands and laminations. Laminated algal structures are mostly preserved within highly salty supratidal to intertidal flat restricted subenvironments because of the environmental dangers and abundance of deposit feeders and grazing animals, particularly gastropods. This can be proven with respect to the presence of these microfacies within evaporite deposits and the presence of evaporite crystals in the dolomitic laminations of stromatolites [13] [14]. Lack of biological variation in microfacies $\mathrm{A}_{4}$ points to the lack of appropriate ecological conditions for marine life [22]-[24]. The presence of fenestral fabric and intraclasts in microfacies $A_{5}$ confirms that this microfacies has been formed within upper intertidal subenvironment. Petrofacies $\mathrm{A}_{6}$ shows the high energy condition in lower intertidal subenvironment. The presence of iron oxide accounts for the abundance of dissolved oxygen, which in turn confirms the shallowness of this subenvironment [8] [25]. Moreover, mature quartzarenite petrofacies is a sign of high flow regimes of intertidal subenvironment [26].

\subsection{Facies Belt B: Lagoon Environment}

This facies belt is composed of three microfacies as follow:

$\mathrm{B}_{1}$ : Sandy Mudstone

This microfacies is made up of $10 \% 0.1 \mathrm{~mm}$-sized quartz grains and a small amount of bioclasts, located in a limemud matrix (Figure 5(a)).
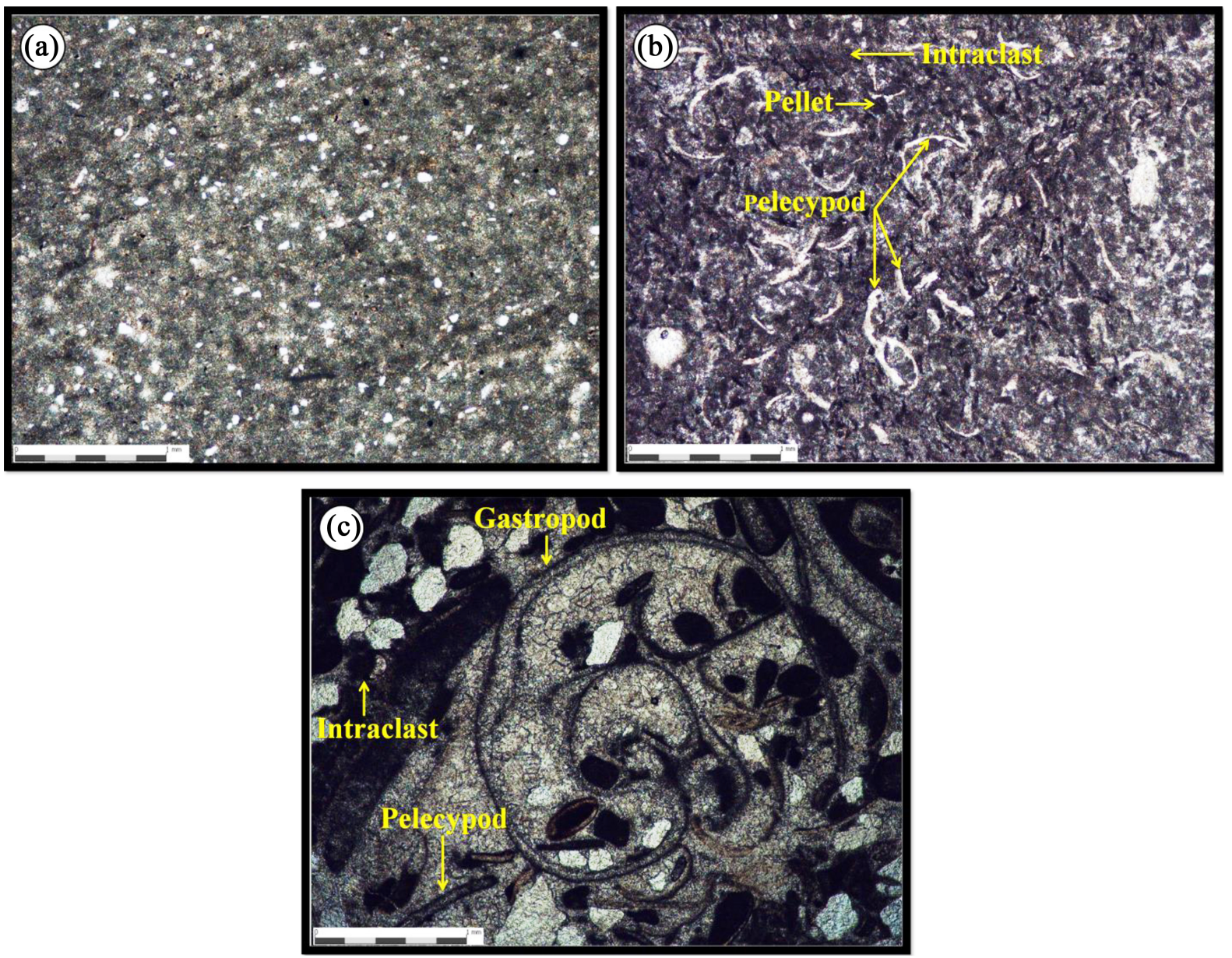

Figure 5. Carbonate microfacies of lagoon environment in Gachal formation, Madbeiki section: (a) Sandy mudstone (b) pellet intraclast pelecypoda wackstone (c) dolomitized sandy intraclast pelecypoda gastropod wackstone. $1 \mathrm{~mm}$ scale. 
$\mathrm{B}_{2}$ : Pellet Intraclast Pelecypoda Wackstone

The most abundant allochems of this microfacies are 15\% $0.6 \mathrm{~mm}$-sized pelecypoda fragments, together with 10\% $0.2 \mathrm{~mm}$-sized intraclast and 5\% $0.1 \mathrm{~mm}$-sized pellet, located in a micritic matrix (Figure 5(b)).

$\mathrm{B}_{3}$ : Dolomitized Sandy Intraclast Pelecypoda Gastropod Packstone

This microfacies consists of 35\% gastropods with $2 \mathrm{~mm}$ in size, 25\% pelecypoda with $1 \mathrm{~mm}$ in size, $10 \%$ intraclast with $0.3 \mathrm{~mm}$ in size and 5\% well-sorted and relatively rounded quartz grains in $0.4 \mathrm{~mm}$, all lain within a micritic matrix. It is noteworthy that dolomitization also occurs in this microfacies (Figure 5(c)).

\section{Interpretation}

Microfacies of this facies belt share such characteristics as presence of lime mud, non-skeletal grains including pellet, intraclasts and lagoonal bioclasts such as pelecypoda and gastropod, capable of surviving in restricted and semi-restricted conditions [27]. The first common characteristics among microfacies of restricted lagoon environment is the presence of tranquility in their formation environment, and the second one is the high level of salinity in the depositional environment of the sediments of this group [24]. The distinctive feature of the microfacies of this group is due to the fabric type and grain size. Lagoon and basins separated from sea by shoal usually show restricted water circulation and have low salinity. The dominant form of deposit in this environment is carbonate, made up mostly of pellet [8]. High amount of quartz grains in microfacies $\mathrm{B}_{1}$ indicates that this microfacies belongs to shallow lagoon environment [24]. According to the extension of lagoonal fauna and development of micritization in microfacies $\mathrm{B}_{2}$ and $\mathrm{B}_{3}$, one can associate these microfacies with lagoon environment [10] [11]. The presence of fecal pellets below the wackstone microfacies $B_{2}$ accounts for the enough oxygen and appropriate nutritional condition [11]. Due to the changes in salinity and freshwater inflows in microfacies $\mathrm{B}_{3}$, the variety of stenohalines is reduced, and appropriate environment and conditions are prepared for the growth of euryhalines such as gastropods and pelecypoda [28]. Survival and preservation of gastropod in these deposits are attributed to low erosion and movement, implying an oxidized, low-energy restricted lagoon environment [14] [29].

\subsection{Facies Belt C: Shoal Environment}

This facies belt consists of six microfacies as follow:

$\mathrm{C}_{1}$ : Cortoid Grainstone

The major allochems of this microfacies are $1 \mathrm{~mm}$-sized micritic bioclast fragments, laid down in a sparry calcite cement matrix, and constitute $65 \%$ of the whole sample (Figure 6(a)).

$\mathrm{C}_{2}$ : Dolomitized Bioclast Grainstone

This microfacies consists of $40 \%$ crinoid, $20 \%$ brachiopod and $15 \%$ gastropod with size of $1 \mathrm{~mm}$, situated in a sparry calcite cement matrix. Also, this microfacies has been influenced by dolomitization process (Figure 6(b)).

$\mathrm{C}_{3}$ : Dolomitized Framestone

The most important allochem of this microfacies is $70 \% 6 \mathrm{~mm}$-sized corals. This microfacies have undergone dolomitization process (Figure 6(c)).

$\mathrm{C}_{4}$ : Crinoid Grainstone

This microfacies is composed of $90 \%$ crinoids with $0.5 \mathrm{~mm}$ in size, dominating a sparry calcite cement matrix (Figure 6(d)).

$\mathrm{C}_{5}$ : intraclast Algal Grainstone

This microfacies is made up of $45 \%$ tubiphyte algae with size of $1.5 \mathrm{~mm}$ and $20 \%$ intraclast with $0.4 \mathrm{~mm}$ in size, laid down within a sparry calcite cement matrix (Figure 6(e)).

$\mathrm{C}_{6}$ : Brachiopod Crinoid Grainstone

This microfacies contains $65 \%$ crinoids and $20 \%$ brachiopods with $1 \mathrm{~mm}$ in size, scattered in a sparry calcite cement (Figure 6(f)).

\section{Interpretation}

This facies belt is formed in shoal environment and below the wave effect due to the presence of skeletal fragments such as crinoid, corals and brachiopod and non-skeletal fragments like intraclast as well as lack of intergranular lime mud [30]. The presence of fully cement matrix, lack of lime mud and size of the grains forming 

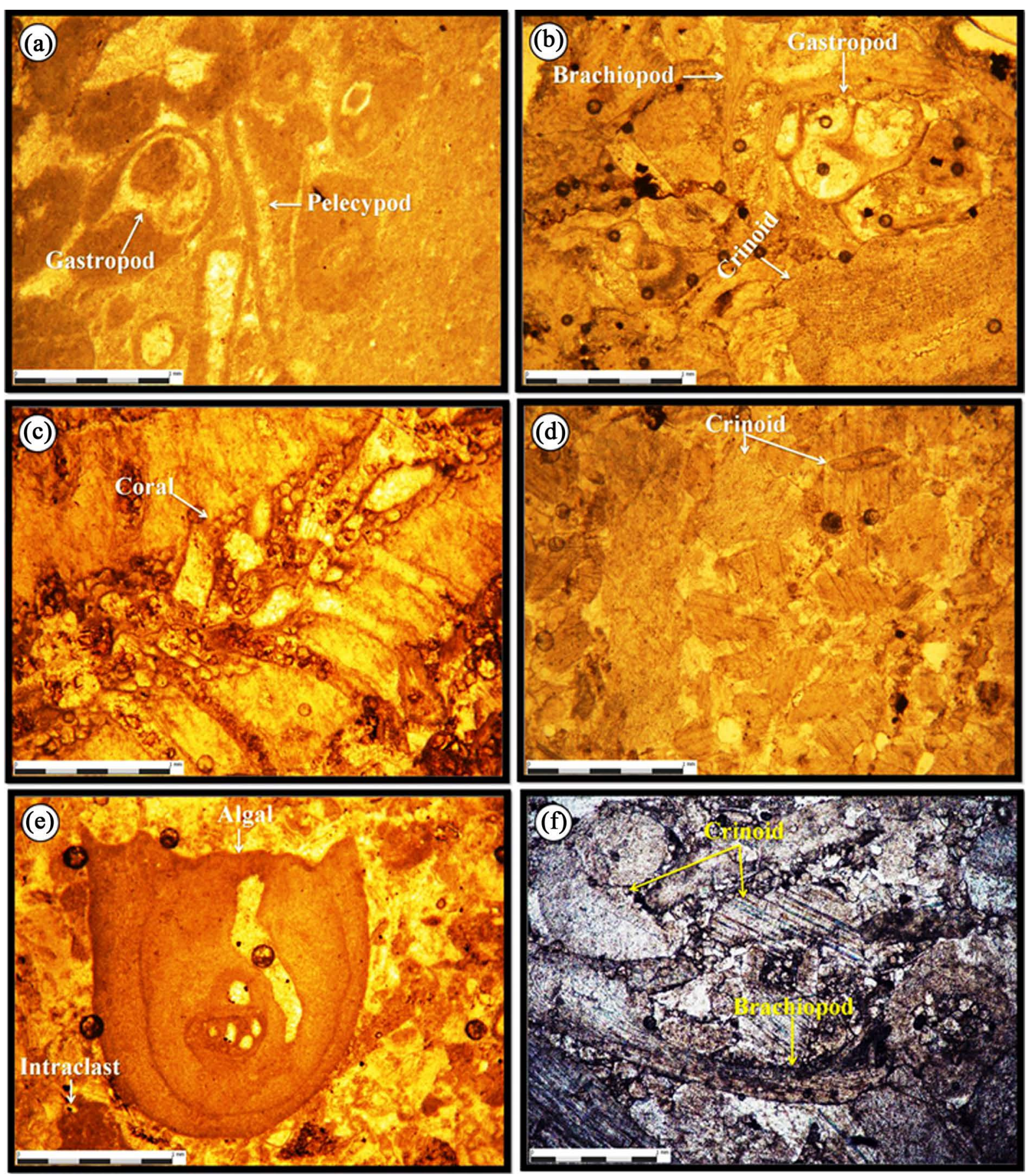

Figure 6. Carbonate microfacies of shoal environment in Gachal formation, Madbeiki section (a) cortoid grainstone (b) dolomitized bioclast grainstone (c) Dolomitized framestone (d) crinoid grainstone (e) intraclast algal grainstone (f) brachiopod crinoid grainstone. $1 \mathrm{~mm}$ scale.

these microfacies indicate the high level of energy during the formation of this microfacies in a shoal environment [31]-[33]. Microfacies $\mathrm{C}_{1}$, as a cortoid grainstone, is mostly covered by micrite. According to Flugel [11], the micritic coverage of the skeletal grains indicate deposition in the area of light influence and depth of lower than 100 - $200 \mathrm{~m}$. The presence of stenohalins like crinoid and brachiopod in microfacies $C_{2}, C_{4}$ and $C_{6}$ points to the association of these microfacies with open marine environment [34]. Lack of a continuous layer of coral and reef in microfacies $\mathrm{C}_{3}$ accounts for the presence of pach reef. Since coral structures in carbonate ramps are found 
in the pach form, they are formed in leeward shoal and lagoon environments [11] and located above the normal waves level [8]. The presence of grainstone and intraclasts in microfacies $C_{5}$ points to its formation in a highenergy environment like shoal environment [11]. According to the evidence, this microfacies can be associated with the seaward shoal [10] [11] [35] [36].

\subsection{Facies Belt D: Open Marine Environment}

This facies belt is composed of three microfacies as follow:

$\mathrm{D}_{1}$ : Sandy Crinoid wackstone

This microfacies includes 15\% 1-mm sized crinoid, located in a micritic matrix. Additionally, it contains 5\% well-sorted and poorly rounded quartz grains with less than $0.1 \mathrm{~mm}$ in size (Figure 7(a)).

$\mathrm{D}_{2}$ : Dolomitized Crinoid Bryozoan Packstone

This microfacies involve $60 \%$ bryozoan and $15 \% 1 \mathrm{~mm}$-sized crinoid, laid down in a micritic matrix. This microfacies is also influenced by dolomitization (Figure 7(b)).

$\mathrm{D}_{3}$ : Dolomitized Sandy Brachiopod Crinoid Packstone

This microfacies is made up of $60 \%$ crinoids, $20 \%$ brachiopod and $5 \%$ well sorted and rounded quarts with $0.6 \mathrm{~mm}$ in size, located within a micritic matrix. These microfacies experience dolomitization (Figure 7(c)).

\section{Interpretation}

The intergranular muddy matrix [37] and abundance of crinoids, brachiopods and bryozoan [8] point to the formation of microfacies $\mathrm{D}_{1}-\mathrm{D}_{3}$ in a low-energy and calm environment like open marine [37]. Regarding the
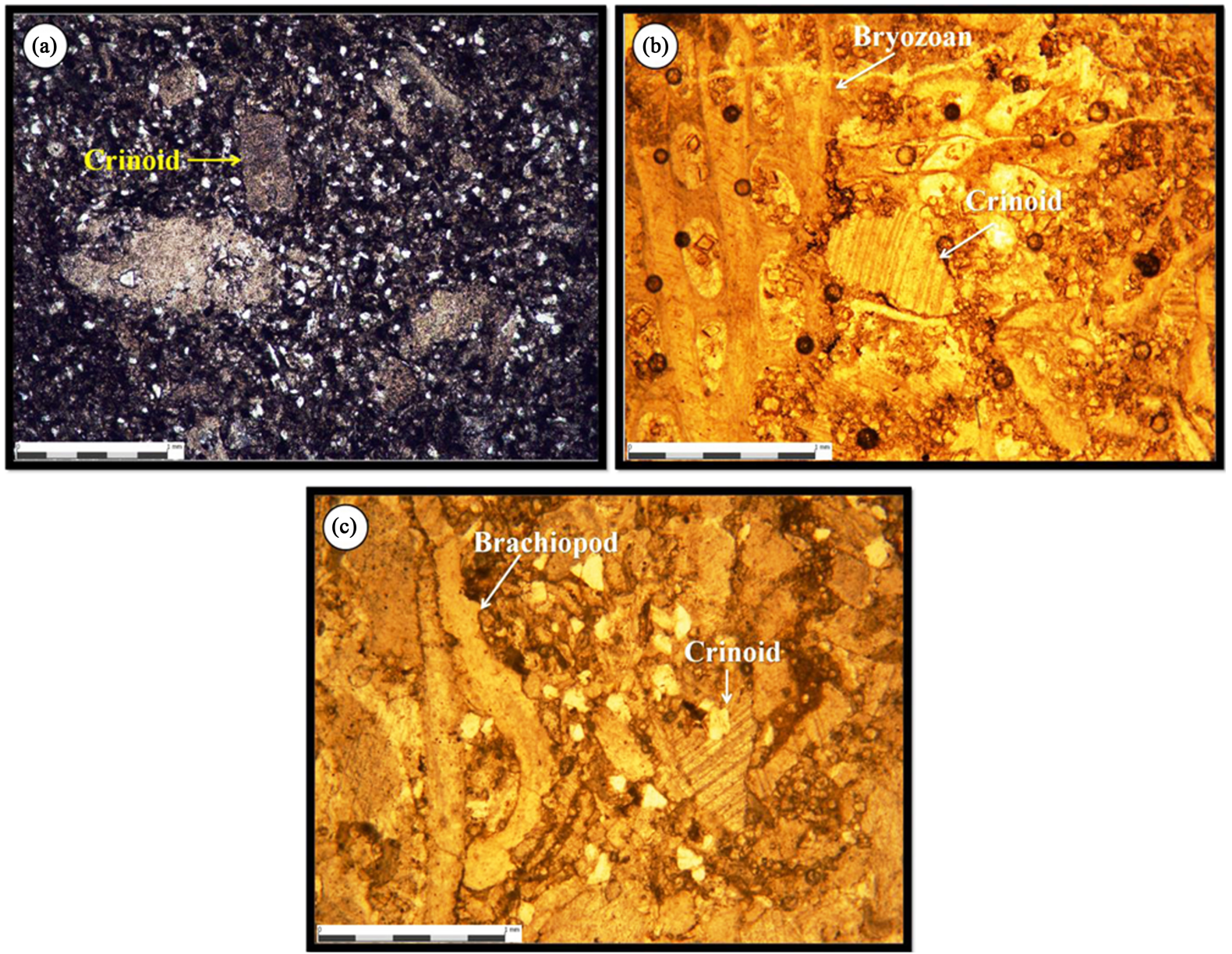

Figure 7. Carbonate microfacies of open marine environment of Gachal formation in Madbeiki section (a) Sandy Crinoid wackstone (b) dolomitized Crinoid bryozoan packstone (c) dolomitized sandy brachiopod crinoid packstone. $1 \mathrm{~mm}$ scale. 
abundance of stenohalins like crinoids and brachipods, this microfacies is formed in a normal saline environment like open marine [11] [14] [38]. Abundance of carbonate mud and reduction in the skeletal fragments size in microfacies $\mathrm{D}_{1}$ suggest the deposition of this microfacies in deep and low-energy open marine environment [11]. The amount of allochems is increased in microfacies $D_{2}$ and $D_{3}$ while the amount of micrite is decreased. The presence of cement and large volume of bioclasts like bryozoan and crinoids indicate that these microfacies are formed in shallow and high-energy like upper open marine environment [11].

\section{Depositional Environment Model of Gachal Formation in Madbeiki Section}

According to the microscopic and field observations, vertical relationship between microfacies and the comparison made between microfacies of Gachal formation and current depositional microfacies, the depositional model of Gachal formation in Madbeiki section is presented in Figure 8. This model represents the position of the formation of siliciclastic petrofacies and carbonate-evaporite microfacies of the mentioned facies in tidal flat, lagoon, shoal and open marine environments. Owning to the lack of calcitorbudite, slumps, barrier reefs and oncolite as well as presence of gradual facies, this petrofacies and its microfacies are formed in a low-angle homoclinal carbonate-evaporite-siliciclastic ramp [27] [39] [40], located in the passive margin of southern Paleotethys ocean [41]. Investigating the microfacies and depositional environment of Gachal formation in Madbeiki

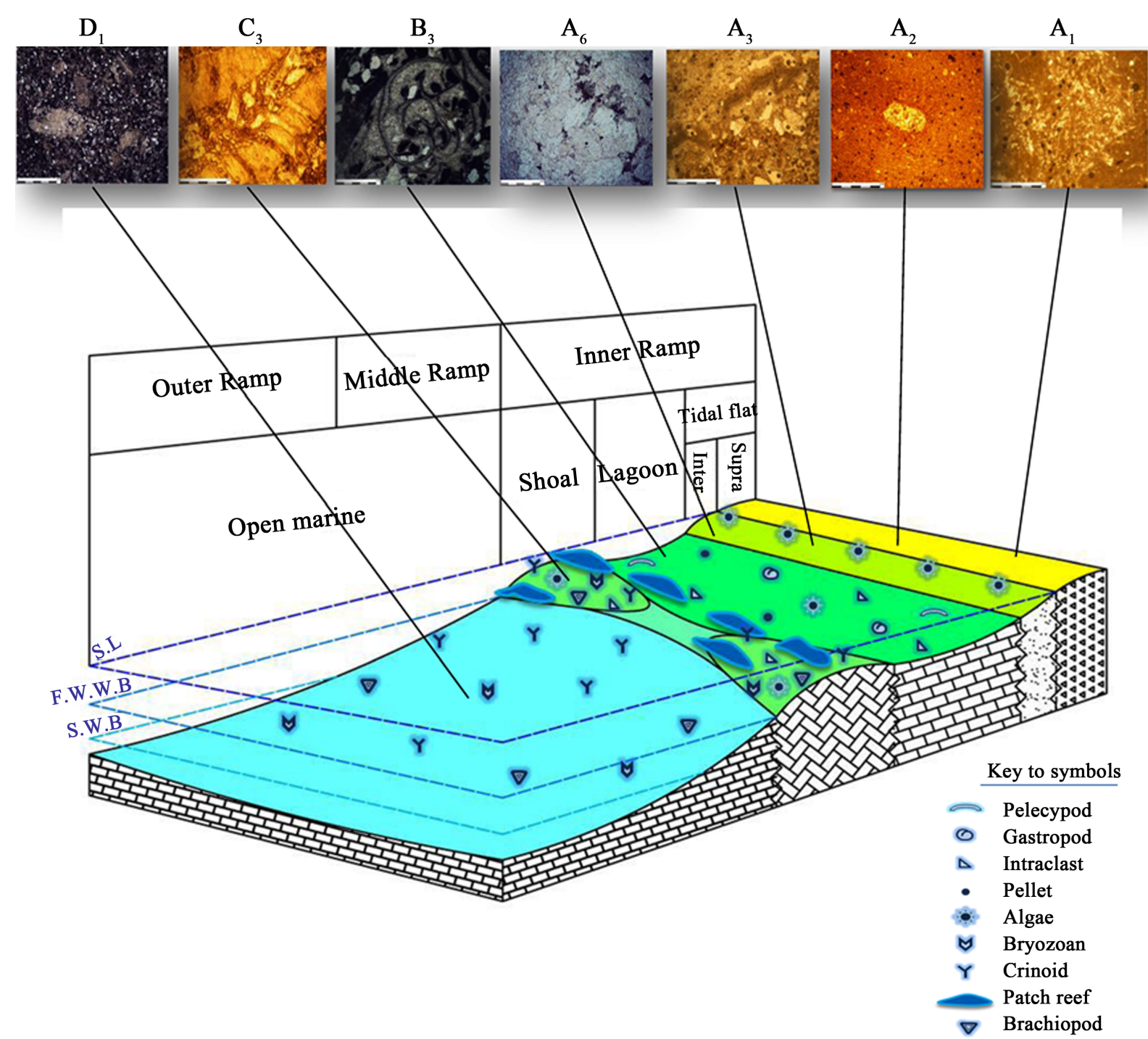

Figure 8. Depositional environment model of Gachal formation in Madbeiki section. 
section indicate that shallow marine environment is observed in lower carboniferous, where various microfacies of Gachal formation are deposited. As can be seen in the proposed model, fenestral fabric and gypsum are common in supratidal flat subenvironment and account for its exit from water and hot and dry weather conditions. Intertidal flat subenvironment hosts the formation of mudstone deposits. Deposits of lagoon environment are laid in a restricted to semi-restricted environment, separated from shoal environment by organisms like corals, contributing to the formation of shoal environment. Open marine environment is characterized by the presence of crinoid fragments in a packstone and wackstone matrix, and its thickness is less than other environments.

\section{The Frequency Column of Microscopic Microfacies}

These microscopic microfacies consist of orthochem and allochem components, the type of matrix or cement and the type of skeletal and non-skeletal. The frequency percentage of allochem is computed by polarizing microscope and depicted separately for each allochem (Figure 9).

\section{Sequence Stratigraphy of Gachal Formation in Madbeiki Section}

Sequence stratigraphy is a method of classifying and interpreting sedimentary rocks and fossils in in terms of variations in the environments [42]. The variation in the weather and sea level can be detected through careful analysis of sequence stratigraphy [43]. According to the literature and various sections of Gachal formation in Madbeiki section, Kalmard block, three third order, siliciclastic-evaporite-carbonate depositional sequences, belonging to Lower Carboniferous are identified. All and all, the source of sediment supply is the first factor causing distinction between carbonate and siliciclastic systems [44].

\subsection{First Depositional Sequence}

As a siliciclastic-carbonate sequence, this 129 m-thick depositional sequence is both overlain and underlain by type 1 sequence boundary. In this sequence, LST system tract unconformably overlies Kalmard formation by extending microfacies of supratidal subenvironment. In this depositional sequence, this LST system tract consists of early LST and late LST. Early LST contains microfacies of tidal flat environment (intertidal subenvironment) such as gypsiferous mudstone and evaporite dolomicrite and siliciclastic petrofacies of tidal flat environment (supratidal subenvironment) like quartzarenite, mostly observed in the desert as white gypsy marl and a sequence of thick-to-medium bedded red sandstone and thick-to-medium bedded yellow dolomite (Figure 9). Late LST is composed of horizontally stratified, medium-bedded sandstones, enjoying quartzarenite petrofacies with progradational stacking pattern. It is possible for this system tract to be formed during a sea level fall. LST system track is $15 \mathrm{~m}$ thick in the desert. One of the consequences of LST in carbonate-siliciclastic systems is the extension of siliciclastic deposits. Once sea level is lower than the edge of the continental shelf, more siliciclastic materials enter the environment [45]. Overlying LST system tract, TS is identified by medium bedded layers of sandy dolomitic limestone with lagoon microfacies (sandy mudstone).

TST system tract, showing deepening trend with retrogradational stacking pattern, consists of carbonate parasequences with tidal flat microfacies (intertidal) (fenestral mudstone), lagoon microfacies (sandy mudstone, Pellet Intraclast Pelecypoda Wackstone, Dolomitized Sandy Intraclast Pelecypoda Gastropod Packstone), shoal microfacies (Crinoid Grainstone, brochipod crinoid grainstone) and open marine microfacies (Sandy Crinoid wackstone and Dolomitized Sandy Brachiopod Crinoid Packstone). This system tract is observable in the desert in terms of a sequence of thick-to-thin bedded dolomitic sandstone and gray dolomitic limestone with horizontally stratified and $64.5 \mathrm{~m}$ in thickness. This system tract is progradationally followed by maximum flooding surface (MFS), identified by sandy crinoidal wackstone microfacies of open marine environment. This surface, preceded by TST system tract, is characterized by horizontally stratified, thin-bedded dolomitic limestone. HST system tract, exhibiting a shallowing trend with progradational stacking pattern, contains open marine, shoal, lagoonal and tidal flat microfacies. This system tracts is characterized by horizontally stratified, thick-to-thin bedded, dark gray dolomitic limestone with $49.5 \mathrm{~m}$ in thickness and consists of open marine microfacies (Dolomitized Crinoid Bryozoan Packstone), shoal microfacies (Dolimitized Crinoid Grainstone and Dolomitized Framestone), lagoonal microfacies (Pellet Interclast Pelecypod Wackestone and Sandy Mudstone) and tidal flat microfacies (Dolomitized Fenestral Stromatolite Boundstone). This sequence finally ends in SB1, characterized 


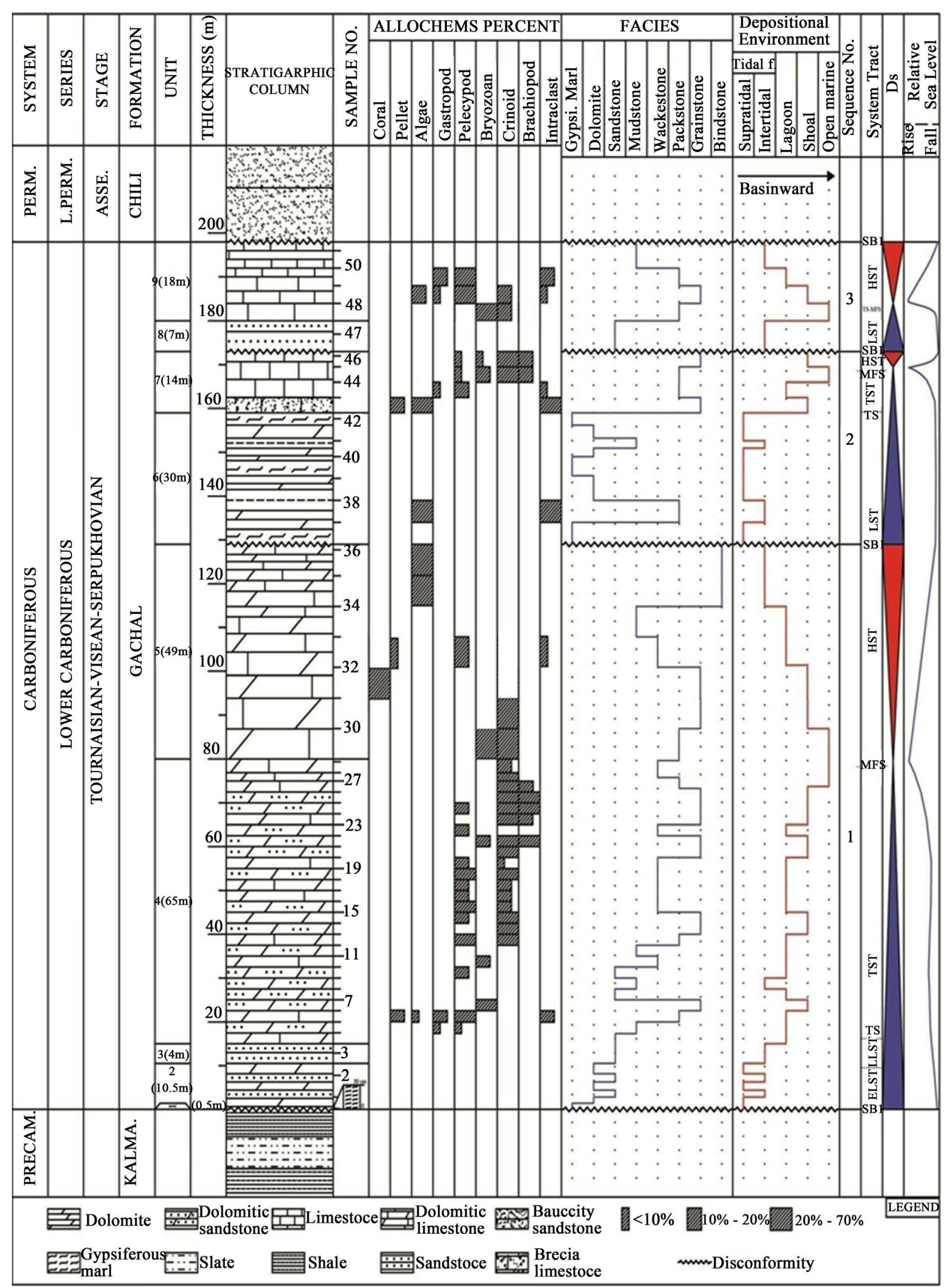

Figure 9. Frequency column of microscopic microfacies and depositional sequence of Gachal formation in Madbeiki section. 
by gypsiferous mudstone microfacies of supratidal subenvironment (Figures 10-12).

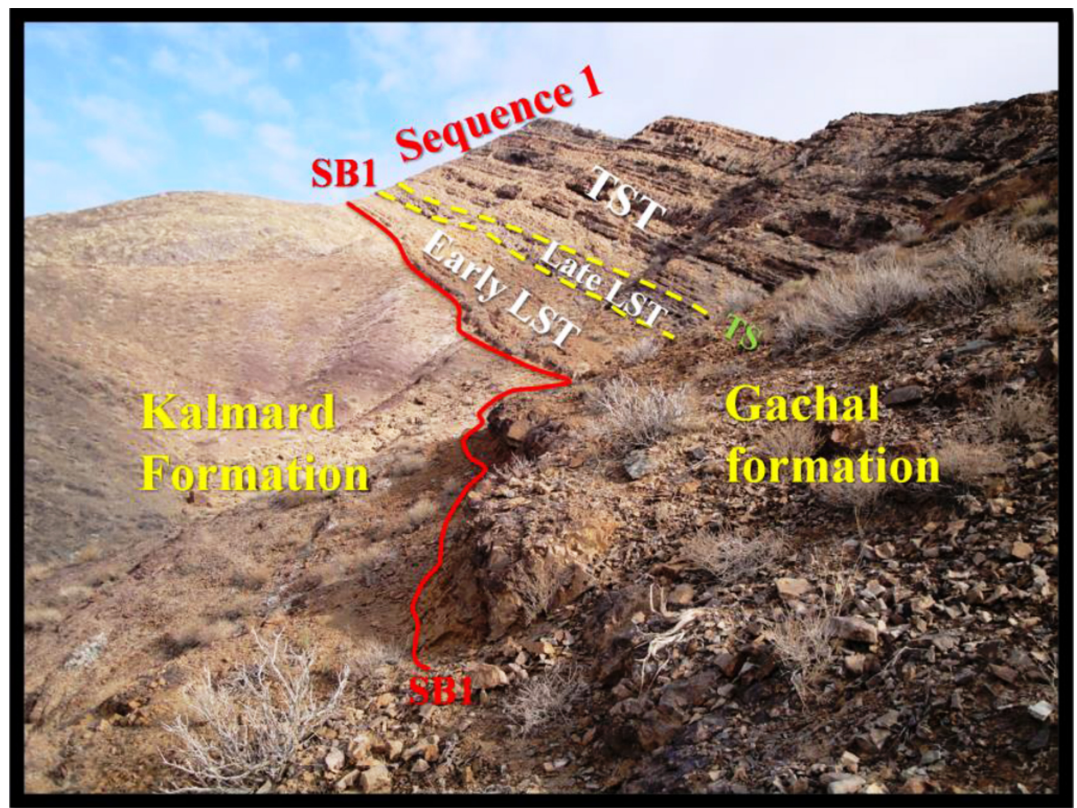

Figure 10. Image of the first depositional sequence of Gachal formation in Madbeiki section: the first sequence contains SB1 and is errosinal. Early LST contains white gypsy marl and a sequence of thick-to-medium bedded reddish dolomitic sandstone and thick-to-medium bedded yellowish dolomite, belonging to tidal flat environment (supratidal subenvironment). Late LST is composed of thick-to-medium bedded red sandstone, which belongs to tidal flat environment (intertidal subenvironment). TS, progradationally overlying LST, is characterized by layers of limestone. TST system tract consists of a sequence of horizontally stratified, thick-to-thin bedded gray dolomitic limestone and dolomitic sandstone, and microfacies of tidal flat (intertidal subenvironment), lagoon, shoal and open marine. $0.5 \mathrm{~m}$ scale.

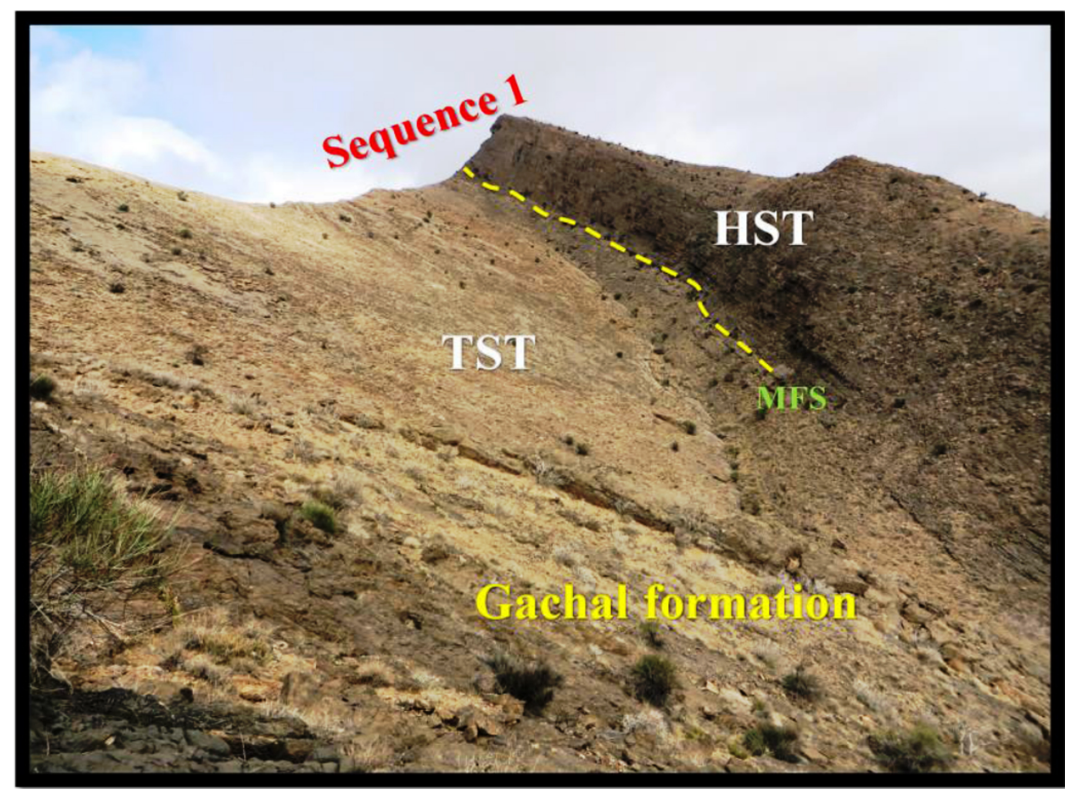

Figure 11. Image of the first depositional sequence of Gachal formation in Madbeiki section: TST system tract consists of a sequence of horizontally stratified, thick-to-thin bedded gray dolomitic limestone and dolomitic sandstone, and microfacies of tidal flat (intertidal subenvironment), lagoon, shoal and open marine. MFS in medium-bedded dolomitic limestone is identified by sandy crinoid wackstone, belonging to open marine environment. Moreover, HST system tract, showing a deepening trend a progradational stacking pattern, is recognized by microfacies of open marine, shoal, lagoon and tidal flat environments and is composed of horizontally stratified, thick-to-thin bedded gray dolomitic limestone. $0.5 \mathrm{~m}$ scale. 


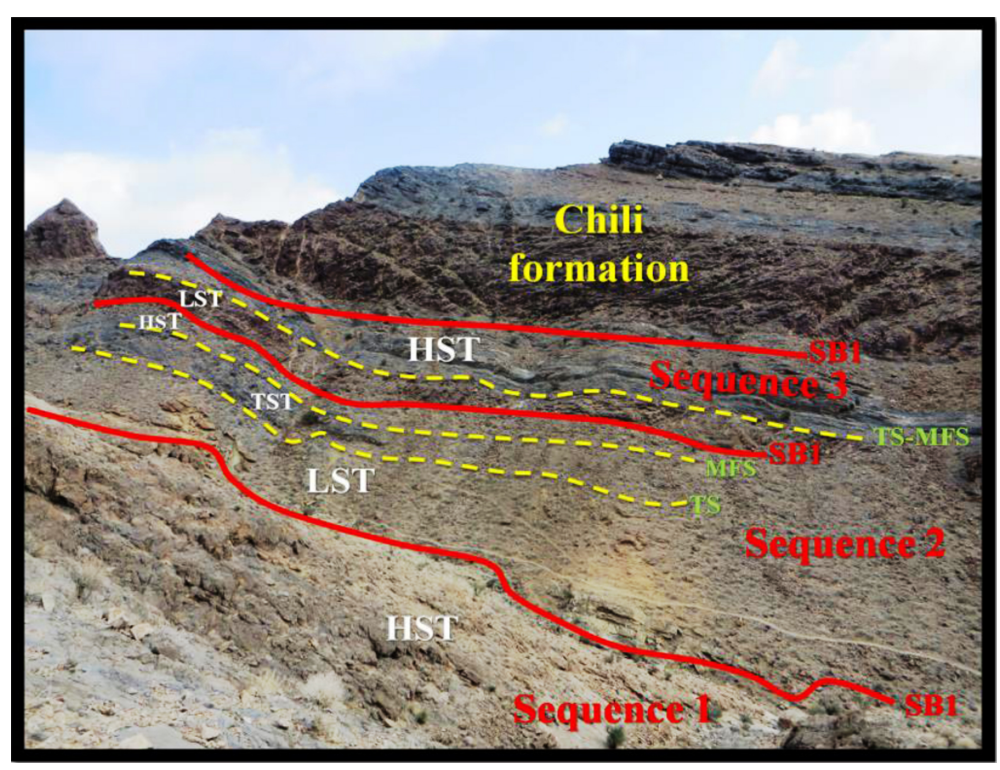

Figure 12. Image of the first, second and third depositional sequences of Gachal formation in Madbeiki section: HST system tract in the first depositional sequence includes horizontally stratified, thick-to-medium, gray dolomitic limestone. LST system tract in the second depositional sequence contains a sequence of dolomite, shale and horizontally stratified medium-to-thin bedded, yellow to green gypsy marl, belonging to tidal flat environment. TS, progradationally overlying LST system tract, is dominated by layers of limestone. TST system tract consists of horizontally stratified, thick-to-thin bedded gray dolomitic limestone with microfacies of lagoon and shoal environments. MFS in thin-bedded gray limestone with dolomitized sandy brachiopod crinoid packstone, belonging to open marine environment. HST, showing a progradational stacking pattern with microfacies of shoal environment, is characterized as medium-to-thin bedded gray limestone. LST system tract in the third depositional sequence contains thick-to-medium bedded, reddish, biturbated sandstones, belonging to tidal flat environment (intertidal subenvironment), TS, progradationally overlying LST system tract, is identified by thin-bedded gray limestone with dolomitized crinoid bryozoan packstone, belonging to open marine environment. HST system tract, showing a deepening trend and a progradational stacking pattern, is recognized by microfacies of open marine, shoal, lagoon and tidal flat environments and is composed of horizontally stratified, thick-to-thin bedded, gray limestone.

\subsection{Second Depositional Sequence}

This $44 \mathrm{~m}$-thick depositional sequence covers the first depositional sequence by type 1 sequence boundary. In this sequence, LST system tract immediately overlies SB1, and tidal flat microfacies are deposited due to the fall in sea level. These microfacies include gypsiferous mudstone and evaporite dolomudstone in supratidal subenvironment while it contains fenestral intraclast algal packstone and fenestral mudstone in intratidal subenvironment. This depositional system tract can be found in the desert in terms of a sequence of dolomite, shale and horizontally stratified, medium-to-thin bedded, yellow to green gypsy marl with $30 \mathrm{~m}$ in thickness (Figure 9). TS has progradationally overlain LST system tract and is characterized by thick-bedded, gray limestone and shoal microfacies (intraclast algal grainstone).

TST system tract, showing deepening trend with retrogradational stacking pattern, consists of carbonate parasequences of lagoon environment (Dolomitized Sandy Intraclast Pelecypoda Gastropod Packstone) and shoal environment (intraclast algal grainstone). TST has $9 \mathrm{~m}$ thickness and is observed as a horizontally stratified, thick-to-thin bedded, gray limestone. Next, MFS can also be found and is characterized by dolomitized sandy brachiopod crinoid packstone. It follows TST system tract and can be observed within horizontally stratified, thin-bedded, gray limestones. HST system tract, showing deepening trend with progradational stacking pattern, consists of shoal microfacies (dolomitized bioclast grainstone) and is characterized by horizontally stratified, medium-to-thin bedded, gray limestone with thickness of $5 \mathrm{~m}$. This sequence is overlain by SB1, identified by quartzarenite petrofacies of intertidal subenvironment (Figure 12).

\subsection{Third Depositional Sequence}

This depositional sequence is $25 \mathrm{~m}$ thick and covers the second depositional sequence by type 1 sequence 
boundary. In this sequence, LST system tract immediately overlies SB1, and siliciclastic petrofacies (Quartzarenite) of tidal flat environment (intertidal subenvironment), showing progradational stacking pattern, is laid due to the fall in sea level. This depositional system tract can be found in the desert in terms of horizontally stratified, thick-to-medium bedded, reddish bioturbated sandstones with $7 \mathrm{~m}$ in thickness (Figure 9). TS and MFS are comply and have progradationally overlain LST system tract and are characterized by dolomitized crinoid bryozoan packstone and can be found in desert as a horizontally stratified thin-bedded, gray limestone.

HST system tract, showing deepening trend with progradational stacking pattern, is characterized in desert by horizontally stratified, thick-to-thin bedded gray limestone with thickness of $18 \mathrm{~m}$ and consists of open marine environment (dolomitized crinoid bryozoan packstone), shoal environment (cortoid grainstone), lagoon environment (Dolomitized Sandy Intraclast Pelecypoda Gastropod Packstone) and tidal flat environment (fenestral mudstone). This sequence finally ends in SB1, containing eroded red lateritic sandstone. These sandstones are associated with Chili formation (lower Permian), unconformably overlain Gachal formation in Madbeiki section (Figure 12).

\section{Interpretation of the Depositional Sequence Identified in Gachal Formation in Madbeiki Section}

According to microscopic investigations, field observations and sequence stratigraphy, Gachal formation in Madbeiki section involves three third order depositional sequences and a lot of high frequency cycle. These sequences are equivalent to upper parts of subordinate large-scale Kaskaskia [46] (asterisk in Figure 13). The lower boundary of the first depositional sequence of Gachal formation in Madbeiki section is a type 1 unconformity, overlying the Precambrian metamorphic deposits (Kalmard formation) and includes white gypsy marl. These deposits are composed of siliciclastic-carbonate deposits, and its MFS is identified by sandy crionidal wackstone microfacies. The second depositional sequence is made up of carbonate and evaporite parasequences. The relative fall in sea level has caused formation of tidal flat deposition (supratidal subenvironment). Its MFS is characterized by dolomitized sandy brachiopod crinoid packstone. The third depositional sequence is like the first one, i.e. is composed of siliciclastic-carbonate deposits. This sequence contains a set of tidal flat to open marine parasequences and its MFS is recognized by dolomitized crinoid bryozoan packstone. In Kalmard siliciclastic-carbonate platform, the sedimentary basin reacts more apparently against sea-level fluctuation due to its shallowness. The sandstones at the beginning of the first and third sequences confirm this claim and points to the rapid change in the conditions. Therefore, one can claim that relative sea level fall leads to the formation of SB1 and thick sandstone horizons between the sequences of Gachal formation and Gachal and Chili boundary. One of the consequences of LST system tract in siliciclastic-carbonate systems is the extension of siliciclastic depositions. Once sea level is lower than the edge of the continental shelf, more siliciclastic materials enter the environment [45].

Regarding the evidence, the sequence model of this formation suggests once the sea water moves forward, calcareous deposits of lagoon, shoal and open marine microfacies are deposited over the sandstone deposits of tidal flat environment. The rate of sea level fall exceeds the rate of tectonic subsidence in SB1, causing the depositional environment to move out of water.

\section{Conclusions}

Having analyzed the facies, depositional environment and sequence stratigraphy of the deposits of Gachal formation in Madbeiki section, the researchers came up with the following results:

Deposits of Lower Carboniferous rocks in Kalmard block are recognized with Gachal informal formation, showing various characteristics in different outcrops. Lower Carboniferous deposits (Gachal formation) are composed chiefly of carbonate, evaporite and siliciclastic rocks. This formation is composed of $198 \mathrm{~m}$ sandstone, limestone and dolomite as well as a small amount of shale, marl and gypsum in the Madbeiki section. Regarding the carbonate compound of the rocks of this formation, along with siliciclastic and evaporite deposits, the rocks of Gachal formation are deposited near the supply source and in a hot and humid weather condition. According to lithologic and microscopic investigations, the deposits of Gachal formation can be divided into 1 siliciclastic petrofacies, 1 evaporite microfacies and 16 carbonate microfacies. Field observations, along with microscopic examinations, have resulted in identifying tidal flat, lagoon, shoal and open marine environments in the rocks of the studied formation. The vertical and lateral changes of microfacies and comparing them with late and early 


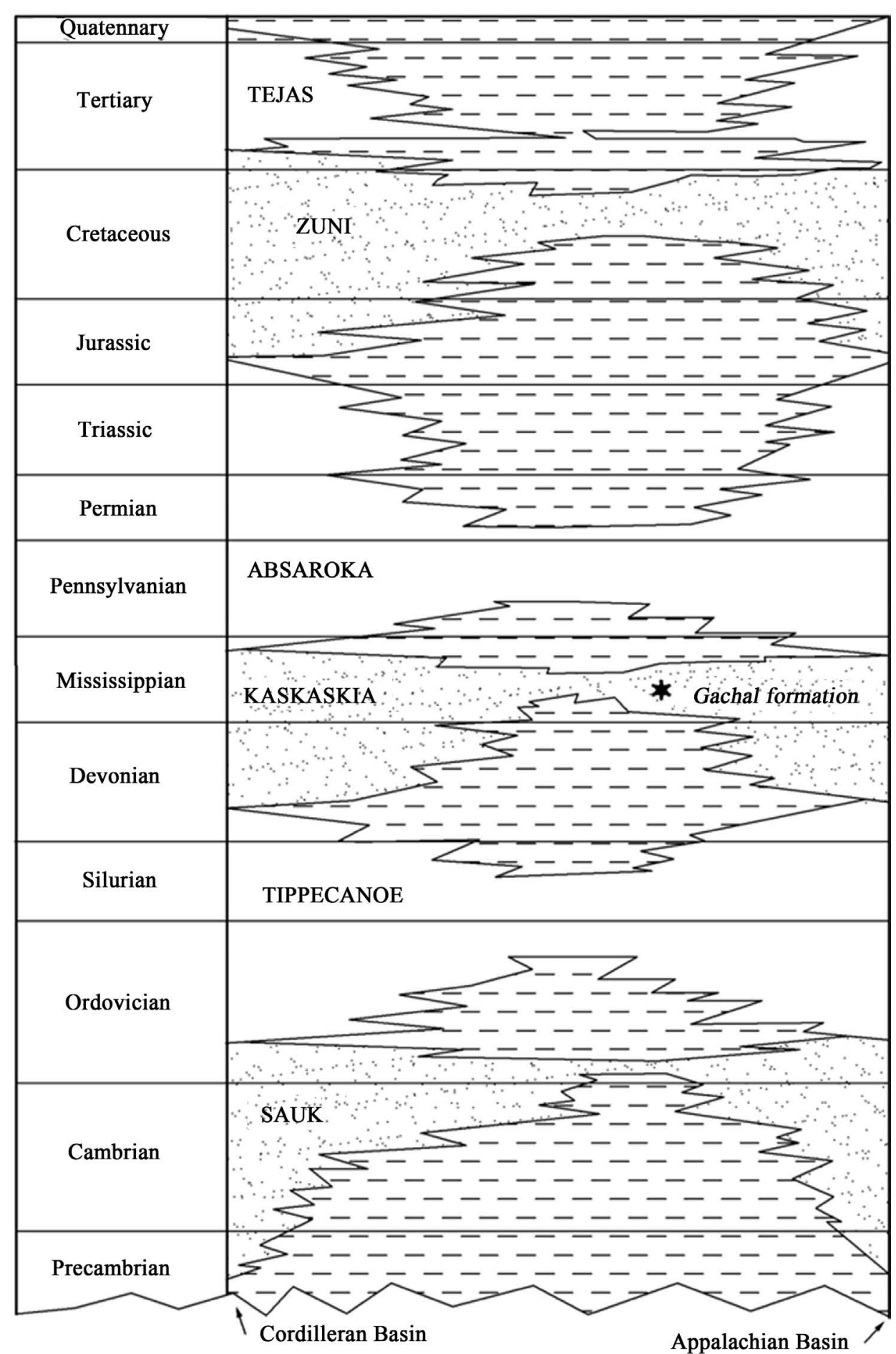

- - Non-deposition

Studied formation time position

Figure 13. Location of Gachal formation in global-scale subsequences is marked by asterisk (Sloss, 1963).

depositional environments indicate that lack of calsitrobudite deposits, slumps, barrier reef and oncolite and presence of gradual facies have caused the mentioned deposits to be formed in a low-angle homoclinal ramp, mostly in the inner ramp, located in the passive margin of southern Paleotethys Ocean. According to the micro- 
scopic investigations, field observations and sequence stratigraphy, the carbonate-evaporite-siliciclastic sequence of Gachal formation is made up of three third-order depositional sequences and lots of high frequency cycles. These sequences are equivalent to upper parts of subordinate large-scale Kaskaskia. The lower boundary of the first depositional sequence of Gachal formation in Madbeiki section is a type 1 unconformity, overlying the Precambrian metamorphic deposits (Kalmard formation) and includes white gypsy marl. This depositional sequence is made up of carbonate-siliciclastic parasequences, and its MFS is identified by sandy crinoid wackstone. The second depositional sequence is composed of carbonate and evaporite parasequences, and its MFS is characterized by dolomitized sandy brachiopod crinoid packstone. The relative fall in sea level results in tidal flat deposits (supratidal subenvironment) at the entry of this sequence. The third depositional sequence is like the first one, i.e. is composed of siliciclastic-carbonate deposits. This sequence contains a set of tidal flat to open marine parasequences and its MFS is recognized by dolomitized crinoid bryozoan packstone. In this sequence, likely sea level fall is likely the result of global-scale glacial and local tectonic activities (subsidence of basin floor and vertical movement of the existing faults). It is noteworthy that the studied area showed no glacial activities like dropstone, Striation and Diamicitite, yet the global sequences are formed as a result of sea level fall on a global scale.

\section{References}

[1] Aghanabati, A. (2004) Geology of Iran. Geological Survey of Iran, Tehran, 606 p.

[2] Aghanabati, A. (1977) Etudgeologique de la region de Kalmard (W. Tabas). Geological Survey of Iran, No. 35 , 51-63.

[3] Azhdari, A. (1999) Geological Map and Report of Robat-e-Khan, on Scale of 1:100000. Geological Survey of Iran, Tehran.

[4] Dickson, J. (1965) A Modified Staining Technique for Carbonate in Thin Section. Nature, 205, 587.

[5] Folk, R.L. (1974) Petrology of Sedimentary Rocks. Hemphill Publishing Company, Austin, 182 p.

[6] Dunham, R.J. (1962) Classification of Carbonate Rocks According to Depositional Texture. In: Ham, W.E., ed., Classification of Carbonate Rocks, a Symposium, AAPG, Tulsano, 108-121.

[7] Embry, A.F. and Klovan, J.E. (1971) A Late Devonian Reef Tract on Northeasterm Banks Island. Bulletin of Canadian Petroleum Geology, 19, 730-781.

[8] Wilson, J.L. (1975) Carbonate Facies in Geologic History. Springer, New York, 471 p. http://dx.doi.org/10.1007/978-1-4612-6383-8

[9] Carozzi, A.V. (1989) Carbonate Rocks Depositional Model. Prentice Hall, Upper Saddle River, 604 p.

[10] Tucker, M.E. and Wright, V.P. (1990) Carbonate Sedimentology. Blackwell Scientific Publication, Hoboken, 496 p. http://dx.doi.org/10.1002/9781444314175

[11] Flügel, E. (2010) Microfacies of Carbonate Rocks, Analysis, Interpretation and Application. Springer-Verlag, Berlin, $996 \mathrm{p}$.

[12] Posamentier, H.M., Jervey, M.T. and Vail, P.R. (1988) Eustatic Controls on Clastics Deposition I-Conceptual Framework. In: Wilgus, C.K., Hasting, B.H., Kendall, C.G.S.C., Posamentier, H.W., Ross, C.A. and Van Wagoner, J.C., Eds., Sea Level Changes: An Integrated Approach, Special Publication, No. 420, SEPM, Tulsa, 109-124. http://dx.doi.org/10.2110/pec.88.01.0109

[13] Adabi, M.H., Salehi, M.A. and Ghabeishavi, A. (2010) Depositional Environment, Sequence Stratigraphy and Geochemistry of Lower Cretaceous Carbonates (Fahliyan Formation), South-West Iran. Journal of Asian Earth Sciences, 39, 148-160. http://dx.doi.org/10.1016/j.jseaes.2010.03.011

[14] Adabi, M.H., Kakemem, U. and Sadeghi, A. (2016) Sedimentary Facies Depositional Environment and Sequence Stratigraphy of Oligocene-Miocene Shallow Water Carbonate from the Rig Mountain, Zagros Basin (SW Iran). Carbonates and Evaporites, 31, 69-85.

[15] Shinn, A. (1983) Tidal Flat Environment. In: Schlle, P.A., Debout, D.G. and Moore, C.H., Eds., Carbonate Depositional Environment, AAPG, Tulsa, 173-210.

[16] Butler, G.P., Harris, P.M. and Kendall, C.G.S.C. (1982) Recent Evaporites from the Abu-Dhabi Coastal Flats. In: Handford, C.R., Loucks, R.G. and Davies, G.R., Eds., Deposition and Diagenetic Spectra of Evaporites, SEPM Core Workshop No. 3, SEPM, Tulsa, 33-64. http://dx.doi.org/10.2110/cor.82.01.0033

[17] Ali, Y.A. and West, I. (1983) Relationships of Modern Gypsum Nodules in Sabkhas of Loess to Compositions of Brines and Sediments in North Egypt. Journal of Sedimentology Petrology, 52, 1151-1168.

[18] Kendall, C.G. and Warren, J.K. (1989) Peritidal Evaporates and Their Sedimentary Assemblage. In: Schreiber, B.C., Ed., Evaporates and Hydrocarbons, Columbia University Press, New York, 66-138. 
[19] Warren, J.K. (1989) Reservoir Analysis and Prediction in Carbonate Sequence Course Organized. National Center for Petroleum Geology and Geophysics, 164-205.

[20] Adabi, M.H. (2009) Multistage Dolomitization of Upper Jurassic Mozduran Formation, Kopet-Dagh Basin, N.E. Iran. Carbonates and Evaporites, 24, 16-32.

[21] Adabi, M.H. (2012) Sedimentary Geochemistry. 2nd Edition, Arian Zamin Publication, Tehran, 504 p.

[22] Adabi, M.H. and AsadiMehmandosti, E. (2008) Microfacies and Geochemistry of the Ilam Formation in the Tang-E Rashid Area, Izeh, S.W. Iran. Journal of Asian Earth Sciences, 33, 267-277. http://dx.doi.org/10.1016/j.jseaes.2008.01.002

[23] AsadiMehmandosti, E., Adabi, M.H. and Wood, D. (2013) Microfacies and Geochemistry of the Middle Cretaceous Sarvak Formation in the Zagros Basin, Izeh Zone, S.W. Iran. Sedimentary Geology, 293, 9-20. http://dx.doi.org/10.1016/j.sedgeo.2013.04.005

[24] Jamalain, M. and Adabi, M.H. (2015) Geochemistry, Microfacies and Diagenetic Evidences for Original Aragonite Mineralogy and Open Diagenetic System of Lower Cretaceous Carbonates Fahliyan Formation (Kuh-e Siaharea, Zagros Basin, South Iran). Carbonates and Evaporites, 30, 77-98. http://dx.doi.org/10.1007/s13146-014-0211-8

[25] Pettijohn, F.J., Siever, R. and Potter, P.E. (1987) Sand and Sandstone. 2nd Edition, Springer-Verlag, Berlin, 553 p. http://dx.doi.org/10.1007/978-1-4612-1066-5

[26] Khalifa, M.A., Soliman, H.E. and Wanas, H.A. (2006) The Cambrian Araba Formation in Northeastern Egypt: Facies and Depositional Environments. Journal of Asian Earth Sciences, 27, 873-884. http://dx.doi.org/10.1016/j.jseaes.2005.09.003

[27] Brandano, M., Frezza, V., Tomassetti, L. and Pedley, M. (2010) Facies Analysis and Palaeoenvironmental Interpretation of the Late Oligocene Attard Member (Lower Coralline Limestone Formation), Malta. Sedimentology, 56, 11381158. http://dx.doi.org/10.1111/j.1365-3091.2008.01023.x

[28] Vachard, D., Flores, A. and Dios, J.E. (2002) Discovery of Latest Devonian/Earliest Mississippian Microfossil in San Salvador Patlanoaya (Puebla, Mexico): Biogeographic and Geodynamic Consequences. Comptes Rendus Geoscience, 334, 1094-1101. http://dx.doi.org/10.1016/S1631-0713(02)01851-5

[29] Hass, J. and Tardy-Filacz, E. (2004) Facies Changes in the Triassic-Jurassic Boundary Interval in an Intraplatform Basin Succession at Csővár (Transdanubian Range, Hungary). Sedimentary Geology, 168, 19-48. http://dx.doi.org/10.1016/j.sedgeo.2004.03.002

[30] Ahmad, A.H.M., Bhat, G.M. and Haris Azim Khan, M. (2006) Depositional Environments and Diagenesis of the Kuldhar and Keera Dome Carbonates (Late Bathonian-Early Callovian) of Western India. Journal of Asian Earth Sciences, 27, 765-778. http://dx.doi.org/10.1016/j.jseaes.2005.06.013

[31] Betzler, C., Braga, J.C., Martin, J.M., Sanchez-Almazo, I.M. and Lindhorst, S. (2006) Closure of a Seaway: Stratigraphic Record and Facies (Guadix Basin, Southern Spain). International Journal of Earth Sciences, 95, 903-910. http://dx.doi.org/10.1007/s00531-006-0073-y

[32] Palma, R.M., Lopez Gomez, J. and Piethe, R.D. (2007) Oxfordian Ramp System (La Manga Formation) in the Bardas Area (Mendoza Province), Neuquén Basin, Argentina: Facies and Depositional Sequence. Sedimentary Geology, 195, 113-134. http://dx.doi.org/10.1016/j.sedgeo.2006.07.001

[33] Khatibi, M. and Adabi, M.H. (2013) Microfacies and Geochemical Evidence for Original Aragonite Mineralogy of a Foraminifera-Dominated Carbonate Ramp System in the Late Paleocene to Middle Eocene, Alborz Basin, Iran. Carbonates and Evaporites, 29, 155-175.

[34] Heckel, P.H. (1972) Recognition of Ancient Shallow Marine Environment. In: Rigby, J.K. and Hemblin, K., Eds., Recognition Ancient Sedimentary Environments. SEPM Special Publication, Vol. 16, SEPM, Tulsa, 226-286. http://dx.doi.org/10.2110/pec.72.02.0226

[35] Maurer, F., Martini, R., Rettori, R., Hillgartner, H. and Cirilli, S. (2009) The Geology of Khuff Outcrop Analogues in the Musandam Peninsula, United Arab Emirates and Oman. GeoArabia, 14, 125-158.

[36] Koehrer, B., Aigner, T. and Poeppelreiter, M. (2011) Field-Scale Geometries of Upper Khuff Reservoir Geobodies in an Outcrop Analogue (Oman Mountains, Sultanate of Oman). Petroleum Geoscience, 17, 3-16. http://dx.doi.org/10.1144/1354-079310-009

[37] Adachi, N., Ezaki, Y. and Liu, J. (2004) The Fabrics and Origin of Peloids Immediately after the End Permian Extinction, Guizhou Province, South China. Sedimentary Geology, 146, 161-178. http://dx.doi.org/10.1016/j.sedgeo.2003.10.007

[38] Bachmann, M. and Hirisch, F. (2006) Lower Cretaceous Carbonate Platform of the Eastern Levant (Galilee and the Golan Heights): Stratigraphy and Second-Order Sea-Level Change. Cretaceous Research, 27, 487-512. http://dx.doi.org/10.1016/j.cretres.2005.09.003 
[39] Read, J.F. (1985) Carbonate Platform Facies Models. AAPG Bulletin, 69, 1-21.

[40] Tucker, M.E. (2008) Sedimentary Petrology. 3rd Edition, Blackwell Publishing, Oxford, 262 p.

[41] Berberian, M. and King, G.C.P. (1981) Towards a Paleogeography and Tectonic Evolution of Iran. Canadian Journal of Earth Sciences, 18, 210-265. http://dx.doi.org/10.1139/e81-019

[42] Naish, T.R., Abbott, S.T. and Carter, R.M. (2013) Sequence Stratigraphy Reference Module in Earth Systems and Environmental Sciences. In: Elias, S.A., Ed., Encyclopedia of Quaternary Science, 2nd Edition, Elsevier, Amsterdam, 260-276.

[43] Patricio, R.D., Luis, A.B., Carlos, O.L. and Gabriela, A.C. (2009) Latest Carboniferous-Earliest Permian Transgressive Deposits in the Paganzo Basin of Western Argentina: Lithofacies and Sequence Stratigraphy of a Coastal Plain to Bay Succession. Journal of South American Earth Sciences, 28, 40-53.

[44] Schlager, W. (2005) Carbonate Sedimentology and Sequence Stratigraphy. SEPM Concepts in Sedimentology and Paleontology 8. SEPM, Tulsa, 200 p. http://dx.doi.org/10.2110/csp.05.08

[45] Alonso-Zarza, A.M. and Tanner, L.H. (2010) Carbonates in Continental Setting: Facies, Environments and Processes. Elsevier, Amsterdam, 225-267.

[46] Sloss, L.L. (1963) Sequence in Cratonic Interior of North America. Geological Society of America Bulletin, 74, 93-114. http://dx.doi.org/10.1130/0016-7606(1963)74[93:SITCIO]2.0.CO;2

\section{Submit or recommend next manuscript to SCIRP and we will provide best service for you:}

Accepting pre-submission inquiries through Email, Facebook, Linkedin, Twitter, etc A wide selection of journals (inclusive of 9 subjects, more than 200 journals)

Providing a 24-hour high-quality service

User-friendly online submission system

Fair and swift peer-review system

Efficient typesetting and proofreading procedure

Display of the result of downloads and visits, as well as the number of cited articles

Maximum dissemination of your research work

Submit your manuscript at: http://papersubmission.scirp.org/ 